\title{
A LOGISTICS REGRESSION MODELLING ON INFANT MORTALITY RATES IN EAST JAVA PROVINCE
}

\author{
Burhanuddin Lazuwardi \\ Department of Biostatistics and Population \\ Faculty of Public Health, Airlangga University, Surabaya, Indonesia \\ Correspondence Address:Burhanuddin Lazuwardi \\ Email: lazuwardi188@gmail.com
}

\begin{abstract}
Infant mortality rate is the number of deaths that occurs between the time after babies are born until they are less than one year old. Broadly speaking, infant mortalities are grouped into endogenous and exogenous infant mortalities. about it was estimated 8.8 million children who were less than 5 years old passed away. The IDHs indicated that infant mortality fell by half, from 68 deaths per 1,000 live births in 1987-1991 to 32 deaths per 1,000 births in 2008-2012. This study was aimed to examine which factors gave the most dominant effect on infant mortality in East Java Province. It used secondary data with a large sample of the total population that consisted of parents whose children died at the age of <12 months. The variables in this study included Infant Mortality Rate (IMR), occupation, education, parity, age of the mothers during pregnancy. access to antenatal care, birth delivery assistance, and Low Birth Weight (LBW). While the effect across variables was examined using a logistic regression test. This study concluded infant mortality rates in East Java showed 34 cases per 1,000 live births. Factors affecting infant mortality rates were education and parity, but those which did not affectinvolved antenatal care, relief, low birth weight, and employment.
\end{abstract}

Keywords: infant birth mortality, logistic regression.

\begin{abstract}
ABSTRAK
Angka kematian bayi adalah kematian yang terjadi antara saat setelah bayi lahir sampai bayi belum berusia tepat satu tahun. Secara garis besar, kematian bayi dikelompokkan menjadi kematian bayi endogen dan kematian bayi eksogen. Diperkirakan terdapat 8,8 juta terdapat anak yang usianya kurang dari 5 tahun meninggal dunia. Angka perkiraan dari SDKI menunjukkan bahwa angka kematian bayi telah turun separuhnya, dari 68 kematian per 1.000 kelahiran hidup pada 1987- 1991 menjadi 32 kematian per 1.000 kelahiran pada 2008-2012. Penelitian ini bertujuan untuk mengkaji faktor apa yang paling berpengaruh dominan terhadap kejadian kematian bayi di Jawa Timur. Penelitian ini menggunakan data sekunder dengan besar sampel total populasi yaitu terdiri dari orang tua dengan kematian bayi pada usia $<12$ bulan. Variabel pada penelitian ini yaitu Angka kematian Bayi (AKB), pekerjaan, pendidikan, paritas, umur ibu saat kehamilan. Akses antenatal care, penolong persalinan saat melahirkan, dan Berat Badan Lahir Rendah (BBLR). Pengaruh antar variabel diuji menggunakan uji regresi logistik. Penelitian ini menyimpulkan bahwa AKB di Jawa Timur menunjukkan 34 kasus setiap 1000 kelahiran hidup. Faktor yang mempengaruhi angka kematian bayi adalah pendidikan dan paritas. Faktor yang tidak mempengaruhi angka kematian bayi yaitu antenatal care, pertolongan persalinan, BBLR dan pekerjaan.
\end{abstract}

Kata kunci: angka kematian bayi, regresi logistik.

\section{INTRODUCTION}

An infant mortality rate is the number of deaths after babies born until at the age of less than one year old $(\leq 12$ months). The infant mortality refers to the infant death at the age of 0 or $\leq 12$ months per 1000 live births or to the probability of infant deaths before being at the age of one year per 1,000 live births (Central Bureau of Statistics, 2003). Infant Mortality Rate (IMR) is measured from the condition in which an infant can survive and reside by looking at the socio-economic and health maintenance. The IMR describes reproductive health further than the infant mortality rate to achieve the goals of the maternal health program for reducing the 
IMR. The maternal healthprogram distributes iron pills and has triggered several other infant health programs, such as the immunization program, child infectious disease prevention program, nutrition program in toddlers (National Population and Family Planning Agency, 2013).

Every year approximately 8.8 million children aged less than 5 years died. This did not indicate a significant decline and deviated from the MDGs goals set by the World Health Organization. The WHO targeted the decrease in infant and toddler mortalities could reach $2 / 3$ in 1990-2015. Meanwhile, in Indonesia, the Infant Mortality Rate (IMR) reached 46 per 1,000 live births, while the newborn mortality rate was 24.8 per 1,000 of live births. To achieve the MDGs goals, the Indonesian government focuses on improving maternal health. Participation between a group of stakeholders is required to rapidly reduce the IMR and Maternal Mortality Rate (MMR). Therefore, the Indonesian Ministry of Health formed a plan for the acceleration action for reducing the MMR. This plan focuses on 3 strategies and 7 main programs, in regards to invite all stakeholders to be involved to have the same concept of maternal and infant mortality issues (National Population and Family Planning Agency, 2013).

The Indonesian Health

Demographic Survey (SDKI) Survey Institute showed the IMR in Indonesia dropped drastically, from 68 deaths per 1,000 live births in 1987-1991 to 32 deaths per 1,000 live births in 2008-2012. It showed a decrease of $41 \%$ neonatal deaths and a decrease of $72 \%$ child or infant mortalities, as well as a decrease of $64 \%$ postnatal deaths. In the past six periods (1991, 1994, 1997, 2002-2003, 2007, and 2012), the survey produced different patterns of decrease in neonatal and infant deaths. The last two surveys showed that the infant and child mortality rate decreased slightly, except the neonatal deaths. The MDGs targets lowering the IMR from 90 deaths per 1,000 live births in 1990 to 23 deaths per 1,000 live births in 2015. All aspects in the health sector need to be improved, in terms of the availability of and access to health facilities, the quantity and quality of health personnel (SDKI, 2012).

The IDHS collects a wide range of information, including infant deaths grouped by socio-economic and biodemographic characteristics. The socioeconomic characteristics include shelter, education, etc. Biodemographic ones includes mother's age, parity, and birth span. Other variables that affect infant deaths include birth weight, antenatal care, and childbirth assistance, as well as complications during childbirth (Winarno, 2009).

Broadly speaking, infant mortalities can be the result of endogenous and exogenous factors. Endogenous mortality occurs when a newborn died in the first month of age due to genetic factors.

The IMR in East Java (source BPS Jatim) accounted for 30 deaths per 1,000 live births in 2005, 36.65 deaths per 1,000 live births in 2012, 28.31 deaths per live births in 2013, 27.23 deaths per 1,000 live births in 2014, and 26.66 deaths per live birthsin 2015. Until 2015, the rate was still above MDGs target of 23 deaths per 1,000 live births (Provincial Health Office, 2014). The IMR in each region of East Java province is very diverse. It raises questions what causes and affects the IMR. Characteristics of regions in East Java determine the quality of health.

It is necessary to research upon factors affecting the IMR to prevent or minimize the IMR in each region.

Factors affecting the IMR was tested by using a regression test. Since this research had a nominal data scale, the logistical regression tests was performed. This test could find a response of relationship between variables that had a nominal data scale or ordinal with two categories or more with one or more predictor variables (Agresti, 1990). This study was aimed to conduct a logistics 
regression modelling on infant mortality rates in East Java province.

\section{METHODS}

The 2012 Indonesian Health Demographics Survey (IHDS) became the secondary data in this study. The survey was derived from the Demographic and Health Surveys (DHS) conducted in all regions in Indonesia. This study only used the 2012 IHDS's data in East Java. This study was conducted in September 2017 to January 2018 in stages, such as proposal drafting, permission, data analysis and reporting the results. The population in the survey was households and women of childbearing age throughout Indonesia. The sampling technique used a multi-stage sampling technique. The survey used the primary sampling unit with a household approach. The sample was obtained as many as 45,607 respondents. After filtering the inclusion criteria, there were 591 respondents participating in the survey. The independent variables included education, parity, antenatal care, delivery assistance during childbirth, Low Birth Weight (LBW), and employment. The data from the survey were downloaded on DHS website.

Then, these data were carried out to processing, filtering or screening, cleaning, recoding stages. The recording stage passed some steps, editing, and coding. This study analyzed factors affecting the IMR using a descriptive analysis and logistic regression test. The descriptive analysis described the frequency distribution and the statistical tables. Th regression test was conducted through SPSS statistical software. This study obtained the ethics of conduct from the Ethics Commission of Faculty of Public Health, Universitas Airlangga, No: 644KEPK.

\section{RESULT}

This study deployed the 2012 Indonesian Health Demographics Survey which involved 591 parents who had an infant mortality at the age of $<12$ months in East Java province. Variables were analyzed to find out the frequency distribution and effect of education on the IMR.

Table 1. Frequency of Education

\begin{tabular}{lll}
\hline $\begin{array}{l}\text { Mother's } \\
\text { Education }\end{array}$ & $\begin{array}{l}\text { Frequen } \\
\text { cy }\end{array}$ & $\begin{array}{l}\text { Presenta } \\
\text { tion }(\boldsymbol{\%})\end{array}$ \\
\hline Not attend school & 6 & 1 \\
\hline Elementary school & 188 & 31.8 \\
\hline Junior high school & 316 & 53.5 \\
\hline Senior high school & 81 & 13.7 \\
\hline Total & 591 & 100 \\
\hline
\end{tabular}

Table 1 shows mothers who gave birth to infants and attended junior high school were the most dominant with a percentage of $53.5 \%$, and there were $31.8 \%$ mothers with elementary school education. Only $1 \%$ of the mothers did not attend schools

Table 2. The number of mothers' children

\begin{tabular}{lll}
\hline $\begin{array}{l}\text { Ever-born } \\
\text { puppies }\end{array}$ & Frequency & $\begin{array}{l}\text { Presentation } \\
(\boldsymbol{\%})\end{array}$ \\
\hline$>2$ child & 119 & 20.1 \\
\hline$\leq 2$ child & 472 & 79.9 \\
\hline Total & 591 & 100 \\
\hline
\end{tabular}

In Table 2, there were 472 mothers who had $\leq 2$ children and 119 mothers who had $>2$ children.

Table 3. Frequency of antenatal care during pregnancy

\begin{tabular}{lll}
\hline $\begin{array}{l}\text { Antenatal } \\
\text { Care } \\
\text { during } \\
\text { pregnancy }\end{array}$ & Frequency & $\begin{array}{l}\text { Presentation } \\
(\boldsymbol{\%})\end{array}$ \\
\hline$<4$ visit & 39 & 6.6 \\
\hline$\geq 4$ visit & 551 & 93.4 \\
\hline Total & 591 & 100 \\
\hline
\end{tabular}


Table 3 displays $6.6 \%$ mothers who visited the antenatal care less than four times, and $93.4 \%$ mothers visited the antenatal care for $\geq 4$ times. There were 507 mothers who got health personnel's assistance, but only 84 mothers did not receive any help from health personnel.

Table 4. Frequency of low birth weight

\begin{tabular}{lll}
\hline $\begin{array}{l}\text { Low birth baby } \\
\text { weight (BBLR) }\end{array}$ & $\begin{array}{l}\text { Frequen } \\
\text { cy }\end{array}$ & $\begin{array}{l}\text { Presenta } \\
\text { tion }(\%)\end{array}$ \\
\hline $\begin{array}{l}\text { Birth weight }< \\
2500 \text { gr }\end{array}$ & 6.4 \\
\hline $\begin{array}{l}\text { Birth weight }>553 \\
2500 \text { gr }\end{array}$ & 93.6 \\
\hline Total & 591 & 100 \\
\hline
\end{tabular}

Based on Table 4, there were 38 mothers with babies' birth weight of $<2500$ gr and 553 mothers with babies' birth weight of $>2500 \mathrm{gr}$.

In terms of education, the IMR mostly occurred to mothers without education, and the next high percentage was found in mothers with elementary education. Given the parity variable, mothers with > 2 children mostly experienced infant mortalities. While, from the antenatal care measure, those with $<4$ visits had higher IMR than those with $\geq 4$ visits.

Additionally, mothers who were assisted by non-health personnel had higher IMR. The analysis showed infants with LBW of $<2500$ were higher at risk of death. A simple logistic regression analysis was used with P-value and Exp (B). The EXP (B) value is the odds ratio of IMR to determine factors affecting the IMR with the formula of $\frac{1}{\operatorname{Exp}(\mathrm{B})}$.

The results showed education significantly affected the IMR. Judging on the odds ratio, mothers with no education were 0.051 more likely to experience infant mortality than those with senior high school education. This study revealed parity significantly affected the IMR. Mothers with > 2 children had 11.6 times to experience an infant mortality compared to mothers who gave birth $\leq 2$ children. The visits of antenatal care significantly affected the IMR. The odds ratio showed < 4 visits had a 0.3 -fold.

Furthermore, health personnel's assistance significantly affected the IMR. Mothers with the help of health personnel were 3.6 times more likely to experience infant mortalities.

The same thing also occurred for the LBW variable which significantly affected the IMR. The possibility of infant deaths with LBW was 0.4 times. Contrastly, work did not significantly affect the IMR.

This study also applied multiple logistics regression. If the significance value was $>0.25$, then the independent variable could not be in the multivariate model. The subsequent analysis of multiple logistics regression was conducted for independent variables, such as education, parity, antenatal care, labor assistance, and LBW for their significance values of $<0.25$.

This study found education and parity affected the IMR. Of these two variables, the initial model of logistic regression was formed.

The logistic regression model was formed after the logistic regression test. The precision of the model using the Hosmer and Lameshow test showed that the model was acceptable because there was no significant difference between the model of the observation value and significance value of 0.606 . The regression model formed based on the value of $\beta$ coefficient is as follows:

$p(y)=\ln \frac{\ln (x)\}}{[1-\pi(x)]}=4,189+0,979$ pendidikan $\left(x_{2}\right)-2,033$ paritas $\left(x_{2}\right)$

The logistic regression model was interpreted from the odds ratio. Table 5 shows uneducated mothers experienced more 2.663 times infant deaths compared to mothers who attended high schools. While mothers whose parity was $>2$ children had 0.131 times possibilities compared to the parity of $\leq 2$ children. Due to negative value of parity, the parity of $>2$ children decreased the birth rate. 


$$
\begin{aligned}
& p=\frac{1}{e^{-\left(4,189+0_{4} 979 \text { pendid ikan }\left(x^{2}\right)-z_{2} 08 s \text { paritas }\left(x_{2}\right)\right]}} \\
& =\frac{1}{e^{\left(-4,189-0,979 \text { pendidikan }\left(x^{2}\right)+z_{0} 08 s \text { paritas }\left(x_{2}\right)\right)}}
\end{aligned}
$$

Mothers without education and with parity of $>2$ children had more possibilities of infant deaths according to the logistic regression model calculation.

Table 5. Education and parity entry based on the logistic regression model.

\begin{tabular}{llll}
\hline Education & Parity & $\begin{array}{c}\text { Chance } \\
\text { of birth } \\
\text { death } \\
\{\mathbf{p}(\mathbf{y})\}\end{array}$ & $\begin{array}{c}\text { Opportunities } \\
\text { Born Alive }\{\mathbf{1 -} \\
\mathbf{p}(\mathbf{y})\}\end{array}$ \\
\hline No School & $\begin{array}{l}>2 \\
\text { child }\end{array}$ & 0,985 & 0.0145 \\
\hline
\end{tabular}

The chance of infant deaths that occurred to mothers without education and with parity of $>2$ child was 0.985 .

\section{DISCUSSION}

The IMR shows the number of infant deaths at the age of not exactly one year per 1,000 live births (Central Bureau of Statistics, 2003) of 591 women giving birth in East Java, 34 mothers (5.8\%) per 1,000 inhabitants experienced infant deaths. Purwantide's research (2010) also showed the 2008 National Socio-Economic Survey had no many differences, noting the proportion of IMR as many as 22 to 32 infant deaths per 1,000 live births.

Based on the education level, there were 24 infant deaths that occurred to mothers without education and 6 infant deaths that occurred to mothers with elementary school education per 1,000 births (Central Bureau of Statistics, 2003), noted that the IMR from low-educated mothers was higher than from highly educated mothers. From this finding, highly educated mothers access more information about maternal and child health treatment. In terms of parity, the highest IMR was found in women with $>2$ children $(20.2 \%)$. Mothers with low parity had better health than those with high parity. There were associations of levels of parity with certain diseases, such as bronchchiale asthma, peptic ulcer, pyloric stenosis, etc., but these factors still require further research (Notoatmodjo, 2003).

The analysis of antenatal care indicated that mothers who made a visit or pregnancy check $\geq 4$ visits had lower chance of infant deaths (5.3\%) Additionally, mothers with health personnel's assistance had lower chance of infant deaths $(4.3 \%)$.

The lowest IMR was found among mothers who received medical assistance during labor (Central Bureau of Statistics, 2003).

The mothers with low-weigth infants experienced infant deaths (5.3\%). Most of them had normal birth weight and did not experience infant deaths $(94.7 \%)$.

The study grouped educational levels into no education, elementary school, junior high school, and senior high school. The results shoed that partial independent educational variables significantly affected the IMR. From the multiple logistics regression analysis using the value of Exp (B), education was proven to significantly affect the IMR with the p-value of 0.001 .

In higher education, exposure to information is more massive. A person with higher education tends to utilize modern healthcare facilities than traditional service facilities because they know advantages and disadvantages of both (Sugiharti.,Sukana,Bambang., Hapsari, 2004). According to the survey, higher levels of education were related to the low risk of infant mortality

The number of ideal family members according to (National Population and Family Planning Agency, 2013) was 4 people consisting of one father, one mother, and two children. A family with $\leq 2$ child was categorized as a small family and with $>2$ categorized as a large family. The results of logistic regression analysis showed parity with the significance value of 0.000 affected the IMR. This was aligned 
with multiple logistics regression showing parity variables affected the IMR. However, (Purwanti., 2011) stated that maternal parity did not affect the IMR.

High parity will cause health care for mothers and babies to be born. One of the health impacts that can arise due to high parity is BBLR which will eventually lead to the occurrence of death in infants when the baby with BBLR does not immediately get the proper handling following the procedure.

The number of siblings may affect the IMR. Mothers with many children have little time and special attention to babies because they do not focus on child caring (Departement Of Health., 2000). Due to this burden of child bearing, the Indonesian government initiated family planning program to reduce the high parity and prevent unwanted pregnancy. The number of children born greatly affects mothers' health (Echkholm and Newland, 1884). While, antenatal care as divided into 2 categories i.e. $<4$ visits and $\geq 4$ visits. The antenacal care variable had a significance value of 0.406 , indicating no effect on the IMR.

Mothers minimally should attend antenatal care at least four visits during the first pregnancy. This could describe the level of protection and quality of health services in pregnant mothers (East Java Provincial Health office,2009). Similarly, the research of Suwantide (2011) stated that there was no effect of pregnancy screening on the IMR, but this finding contradicts that of Sum'mur (2004).

Antenatal care was aimed to monitor the development of maternal health and risks (Rachmawati, 2004). This program also has a purpose to maintain maternal health, proper baby treatment, and normal birth. Labor relief was divided into 2; health personnel and non health personnel. the labor relied had P-value of 0.508, indicating its effect on infant mortality. The utilization of labor relief services from non-health personnel has resulted in the incidence of neonatal deaths. Childbirth by doctors, midwives, or health personnel will certainly be safer compared to non-health personnel. Labor with medical assistance is more sterile because it applies certain procedures from the health sciences.

Relief by shamans had a higher risk of infant mortality than by midwives or physicians (Basuki et al., 1996).

The LBW was divided into 2 categories; < 2500 gr and > 2500 gr. The LBW had a significance value of 0.579 , indicating no effect on the IMR. This finding was similar to (Purwanti., 2011). stating that LBW was not related to the incidence of infant mortality.

Essentially, LBW was related to many factors, including the history of premature birth, antepartum bleeding, lack of nutrients during pregnancy, hypertension, maternal age less than 20 years or more than 35 years, too close birth span, infections, trauma, and parity. Fetal factors involved congenital defects, double pregnancies, and hidramnio. Also, low socio-economic conditions and habits become factors causing LBW (Sarwono, 2005).

The multiple logistics regression test between education and parity showed these variables affected the IMR. Mothers without education and with parity of $>2$ children experienced infant deaths more. High parity had an impact on the emergence of various maternal and child health problems (Purwanti., 2011). It also affected the way the family organizes spending for primary needs (Qurniyawaty, 2015)

\section{CONCLUSION}

This study concluded the IMR in East Java was amounted to 34 deaths per 1,000 live births and factors affecting the IMR included education and parity. While, antenatal care, labor relief, BBLR, and occupation did not affect the IMR. Local primary healthcare centers have to conduct data collection, accommodate and 
coordinate coaching and training for health professionals. Primary healthcare centers have to further improve their counseling, especially about the dangers of infant mortality, and to provide media for promoting health literacy, such as advertisements, stickers, posters, etc. They also need to conduct counseling guidance once a week or 2 weeks to pregnant mothers.

\section{REFERENCE}

Central Bureau of Statistics, 2003. Survei Demografi dan Kesehatan Indonesia 2002-2003. Jakarta : Central Bureau of Statistics.

National Population and Family Planning Agency(BKKBN), 2013. Keluarga Berencana dan Kesehatan Reproduksi. Jakarta: National Population and Family Planning Agency (BKKBN).

Departement of Health., 2000. Tanda Bahaya pada Kehamilan, Persalinan dan Nifas. Jakarta: Ditjen Binkesmas.

Provincial Health Office, 2014. Profil Kesehatan Jawa Timur 2014. Surabaya:

Hastono, S., 2007. Analisa Data
Kesehatan. Jakarta: Universitas Indonesia.

Purwanti., 2011. Faktor yang Mempengaruhi Angka Kematian Bayi (AKB) di Provinsi Jawa Timur. Qurniyawaty, E., 2015. Hubungan Usia Ibu Hamil, Jumlah Anak dan Jarak Kehamilan dengan

KejadianKehamilan Tidak Diinginkan (KTD)(di Bidan Praktek Mandiri Titik Hariningrum, Kota Madiun. Tesis. Universitas Sebelas Maret.

Sugiharti., Sukana, Bambang., Hapsari, D., 2004. Hubungan Karakteristik Sosial Ekonomi Ibu dengan Pemanfaatan Tenaga Kesehatan sebagai Penolong Persalinan di Pulau Jawa (Analisis Data Sekunder Susenas 2001). Jurnal Ekologi Kesehatan, 3(2).

Winarno, D., 2009. Analisis Angka Kematian Bayi di Jawa Timur dengan Pendekatan Model Regresi Spasial. Tesis. Institut Teknologi Sepuluh Nopember Surabaya.

Zaenab, J., 2008. Beberapa Faktor Risiko Kejadian BBLR di Rumah Sakit Al FatahAmbon Periode Januari Desember Tahun 2006. 